\title{
Studies on ovarian prostaglandin production in relation to ovulation in the rat*
}

\author{
Carol G. Brown $\dagger$ and N. L. Poyser \\ Department of Pharmacology, University of Edinburgh, 1 George Square, Edinburgh EH8 9JZ, U.K.
}

\begin{abstract}
Summary. Prostaglandin (PG) and thromboxane (TX) synthesizing capacities of the rat ovary were measured at 4-h intervals during the 4-day oestrous cycle of the rat. Production of PGE-2, PGF-2 $\alpha$, 6-oxo-PGF- $1 \alpha$ and TXB-2 increased 5-fold, $1 \cdot 6$-fold, 1-7-fold and 1-7-fold, respectively, between $18: 00 \mathrm{~h}$ on the day of pro-oestrus and $02: 00$ $h$ at oestrus. This preferential stimulation of ovarian PGE-2 production, after the ovulatory surge of LH before ovulation, provides further evidence for the involvement of ovarian PGE-2 in ovulation in the rat. These increases in ovarian PG production were not due to differences in arachidonic acid availability, PG metabolism, or the interconversion of PGE-2 and PGF-2 $\alpha$. In addition, the greater stimulation of PGE-2 synthesis was not due to an increase in PGH-2 to PGE-2 synthetase activity. It is concluded that the ovulatory LH surge late in the afternoon of pro-oestrus in the rat causes an increase in ovarian cyclo-oxygenase (PGH-2 synthetase) activity with the majority of the PGH-2 synthesized being directed into the PGE-2-forming pathway.
\end{abstract}

\section{Introduction}

Ovulation is dependent on increased ovarian prostaglandin (PG) production in many species, including the rat (see Behrman, 1979; Lindner et al., 1980). PGE-2 is very effective in producing follicular rupture in rats in which ovulation has been blocked with indomethacin (Tsafriri, Lindner, Zor \& Lamprecht, 1972). Concentrations of PGE and PGF in rat ovarian follicles increase 70-fold and 18-fold, respectively, and the PGE to PGF ratio reverses in favour of PGE, from the afternoon of pro-oestrus to the time of ovulation (LeMaire, Leidner \& Marsh, 1975). Ovarian PG synthetase activity (measured only as the amount of PGE synthesized) increases with the increase in ovarian PG content (Bauminger \& Lindner, 1975). These changes are prevented in the 'pentobarbitoneblocked' rat or by treating rats with antiserum to $\mathrm{LH}$, and are restored in the 'pentobarbitoneblocked' rat by the administration of LH (Bauminger \& Lindner, 1975). Stimulation of PGE production in rat ovarian follicles in vitro by $\mathrm{LH}$ occurs only after a lag period of $3 \mathrm{~h}$ and is inhibited by protein synthesis inhibitors (Clark, Marsh \& LeMaire, 1976; Zor, Strulovici, Nimrod \& Lindner, 1977). All these authors concluded that the stimulation of ovarian PGE production by LH in the rat is dependent on the de-novo synthesis of one or more components of the PG synthetase enzyme complex rather than on substrate availability (Zor et al., 1977; Clark et al., 1978). However, it is not yet known which components of this enzyme complex are stimulated to cause a relatively specific increase in ovarian PGE-2 production. The main aim of this study was to establish which components of the enzyme complex are being stimulated to increase PGE-2 synthesis. In addition, enzymes are present in the rat ovary which interconvert PGE-2 and PGF- $2 \alpha$ and thus may

\footnotetext{
* Reprint requests to Dr N. L. Poyser.

$\uparrow$ Present address: Department of Biochemical Endocrinology, Chelsea Hospital for Women, Dovehouse Street, London SW3 6LT, U.K.
} 
influence ovarian PG concentrations (Watson, Shepherd \& Dodson, 1979). The relative contribution of this interconversion in controlling PGE-2 production by the rat ovary has also been investigated. In a previous study, ovarian PG and thromboxane (TX) synthesizing capacities were measured between $10: 00 \mathrm{~h}$ and 12:00 h on each day of the 4-day oestrous cycle in the rat. No significant changes in these capacities were found (Poyser \& Scott, 1980. However, any changes in ovarian PG and TX synthesizing capacities associated with ovulation would have been missed in that study. Consequently, ovarian PG and TX synthesizing capacities have now been measured at 4-h intervals throughout the 4-day oestrous cycle of the rat.

\section{Materials and Methods}

\section{Experiments}

Wistar rats weighing 200-250 g were housed under controlled lighting conditions (lights on $06: 00-20: 00 \mathrm{~h}$ ). Vaginal smears were taken daily and examined microscopically. Oestrus was taken as the day of maximum cornification preceding the day of leucocytic infiltration. All rats had shown at least two regular 4-day cycles before being used in one of the following experiments.

Experiment 1 . Six rats were killed at $02: 00,06: 00,10: 00,14: 00,18: 00$ and $22: 00 \mathrm{~h}$ on each day of the 4-day cycle (total no. = 144 rats). The ovaries from each rat were removed, weighed and homogenized in $15 \mathrm{ml}$ Krebs' solution (for composition, see Mitchell, Poyser \& Wilson, 1977). (The hypothalamus and uterus were also removed from these rats and used in other studies.) Each ovarian homogenate was incubated at $37^{\circ} \mathrm{C}$ for $90 \mathrm{~min}$, and aerated with $95 \%$ oxygen and $5 \%$ carbon dioxide. After incubation, the $\mathrm{pH}$ of each incubate was adjusted to 4.0 with $1 \mathrm{~N}-\mathrm{HCl}$, and the lipids were extracted by shaking twice with two volumes of ethyl acetate. The two ethyl acetate fractions were combined and were evaporated to dryness on a rotary evaporator at $45^{\circ} \mathrm{C}$. Each dried extract was redissolved in $10 \mathrm{ml}$ ethyl acetate and stored at $-20^{\circ} \mathrm{C}$ until the amounts of PGE-2, PGF- $2 \alpha, 6$-oxo-PGF- $1 \alpha$ and TXB-2 were measured by radioimmunoassay. Recovery is high $(>80 \%$ ) by the extraction method used (Poyser \& Scott, 1980; Swan \& Poyser, 1983), and so the results were not corrected for procedural losses. After being assayed, all the ovarian extracts were pooled, purified further by silicic acid column chromatography and analysed by gas chromatography-mass spectrometry (GC-MS), as described by Poyser (1983).

Experiment 2. Rats were killed at $10: 00 \mathrm{~h}$ on the day of pro-oestrus and $02: 00 \mathrm{~h}$ on the day of oestrus ( 3 rats at each time). The ovaries of each rat were removed, weighed and homogenized in $15 \mathrm{ml}$ ethanol. Each homogenate was centrifuged at $1000 \mathrm{~g}$ for $15 \mathrm{~min}$, and the supernatant liquid was withdrawn and evaporated to dryness. Each extract was dissolved in $10 \mathrm{ml}$ water, and the PGs and TX were extracted, stored and measured as in Exp. 1.

Experiment 3. Four rats were killed at 10:00 h on the day of pro-oestrus. The ovaries were removed, weighed, homogenized and incubated, and the amounts of PGs were measured as in Exp. 1 , except that arachidonic acid $(2 \mu \mathrm{g} / \mathrm{ml})$ was added to each homogenate before incubation.

Experiment 4. Rats were killed at 10:00 h on the day of pro-oestrus and $02: 00 \mathrm{~h}$ of oestrus (4 rats at each time). Each ovary from each rat was homogenized in $5 \mathrm{ml} \mathrm{Krebs'} \mathrm{solution,} \mathrm{and} 0.5 \mu \mathrm{Ci}$ $\left[{ }^{3} \mathrm{H}\right] \mathrm{PGF}-2 \alpha$ (sp. act. $160 \mathrm{Ci} / \mathrm{mmol}$; Amersham, U.K.) was added to each homogenate. In addition, nicotinamide-adenine dinucleotide (NAD $\left.{ }^{+} ; 2 \mathrm{~mm}\right)$ and PGF- $2 \alpha(2 \mu \mathrm{g} / \mathrm{ml})$ were added to one of the ovarian homogenates from each rat. Each homogenate was incubated and the lipids extracted as in Exp. 1. This study was repeated with a further 8 rats except that $0.5 \mu \mathrm{Ci}\left[{ }^{3} \mathrm{H}\right] \mathrm{PGE}-2$ (sp. act. 160 $\mathrm{Ci} / \mathrm{mmol}$; Amersham, U.K.) and PGE-2 $(2 \mu \mathrm{g} / \mathrm{ml})$ were substituted for $\left[{ }^{3} \mathrm{H}\right] \mathrm{PGF}-2 \alpha$ and PGF- $2 \alpha$, respectively.

All the extracts were analysed by thin-layer chromatography (t.l.c.) using pre-coated silica gel t.l.c. plates (Merck, U.K.) and a solvent system of chloroform, methanol, glacial acetic acid and water in the ratio of $90: 9: 1: 0.65$ (by vol.). Standard t.l.c plates onto which had been spotted $10 \mu \mathrm{g}$ 
each of PGE-2, PGF-2 $\alpha$, 15-keto-PGE-2, 15-keto-PGF-2 $\alpha, 13$,14-dihydro-15-keto-PGE-2, and 13,14-dihydro-15-keto-PGF-2 $\alpha$ were analysed similarly. Substances on the standard plates were visualized by exposure to iodine vapour for $30 \mathrm{~min}$. The silica gel was scraped off the radioactive plates at $0.5 \mathrm{~cm}$ intervals into scintillation vials. After adding $0.5 \mathrm{ml}$ methanol, $10 \mathrm{ml}$ scintillation fluid (10.5 $\mathrm{g}$ 2,5-diphenyloxazole in 2.51 toluene) were dispensed into each vial and the amount of radioactivity present was measured. The $R_{\mathrm{F}}$ values of the radioactive compounds were compared with the $R_{\mathrm{F}}$ values of the standard PGs and PG metabolites. The amount of radioactivity associated with a PG metabolite was corrected for the ioss of a tritium from the carbon at position 15. PG metabolism was calculated by expressing the amount of radioactivity of each PGmetabolite as a percentage of the total radioactivity on the t.l.c. plate.

Experiment 5. Three rats were killed at $02: 00 \mathrm{~h}$ on the day of oestrus and the ovaries were removed. Each ovary was homogenized in $5 \mathrm{ml} \mathrm{Krebs'} \mathrm{solution} \mathrm{and} \mathrm{to} \mathrm{each} \mathrm{homogenate} \mathrm{was} \mathrm{added}$ $0.5 \mu \mathrm{Ci}\left[{ }^{3} \mathrm{H}\right] \mathrm{PGF}-2 \alpha$. To one ovarian homogenate from each rat was added also nicotinamideadenine dinucleotide phosphate (NADP $\left.{ }^{+} ; 2 \mathrm{~mm}\right)$ and PGF- $2 \alpha(2 \mu \mathrm{g} / \mathrm{ml})$. The homogenates were incubated, extracted and analysed by t.l.c. as in Exp. 4. This study was repeated using another 3 rats but substituting $0.5 \mu \mathrm{Ci}\left[{ }^{3} \mathrm{H}\right] \mathrm{PGE}-2$, PGE-2 $(2 \mu \mathrm{g} / \mathrm{ml})$ and reduced nicotinamide-adenine dinucleotide phosphate (NADPH; $2 \mathrm{mM}$ ) for $\left[{ }^{3} \mathrm{H}\right] \mathrm{PGF}-2 \alpha, \mathrm{PGF}-2 \alpha$ and $\mathrm{NADP}^{+}$, respectively. The percentage interconversion of PGE-2 and PGF- $2 \alpha$ in rat ovarian homogenates was determined.

Experiment 6. Rats were killed at $10: 00 \mathrm{~h}$ of pro-oestrus and $02: 00 \mathrm{~h}$ of oestrus $(6 \mathrm{rats}$ at each time). The ovaries were removed, placed in $9 \mathrm{ml} \mathrm{Krebs'} \mathrm{solution} \mathrm{containing} 50 \mu \mathrm{g}$ flurbiprofen (Boots Co. Ltd, Nottingham)/ml and homogenized. Each homogenate was then equally divided amongst 3 flasks, and $100 \mu$ l of each homogenate were taken for the estimation of protein content (Lowry, Rosebrough, Farr \& Randall, 1951). One flask was placed in boiling water for $10 \mathrm{~min}$, then cooled on ice. During this period, the remaining two flasks were kept on ice. The 3 flasks were then incubated for $3 \mathrm{~min}$ to allow the temperature of the homogenates to reach $25^{\circ} \mathrm{C}$. Flasks were aerated with $95 \%$ oxygen and $5 \%$ carbon dioxide. PGH-2 $(1 \mu \mathrm{g}$ in $200 \mu \mathrm{l} \mathrm{Krebs'} \mathrm{solution)} \mathrm{was} \mathrm{added} \mathrm{to} \mathrm{the}$ flask containing the boiled homogenate and to one other flask to measure non-enzymic breakdown of PGH-2 and enzymic transformation, respectively. In the third flask, basal PG production in the presence of a high concentration of a cyclo-oxygenase inhibitor was measured. The 3 flasks were incubated for a further $1 \mathrm{~min}$ at $25^{\circ} \mathrm{C}$ and then $0.5 \mathrm{ml}$ stannous chloride in ethanol $(50 \mu \mathrm{g} / \mathrm{ml})$ was added. Stannous chloride reduces any remaining PGH-2 to PGF-2 $\alpha$ (Hamberg \& Samuelsson, 1973). All incubates were extracted as in Exp. 1, and the PGE-2 content was measured by RIA.

PGH-2 was stored in hexane and ethyl acetate $(60: 40 \mathrm{v} / \mathrm{v})$ at $-20^{\circ} \mathrm{C}$. Before use, the solvent was evaporated under reduced pressure at $0^{\circ} \mathrm{C}$. The residue was dissolved in the required volume of ice-cold Krebs' solution. The initial PGH-2 concentration, after reduction to PGF-2 $\alpha$, was estimated by GC-MS (Poyser \& Scott, 1980).

\section{Details of radioimmunoassay}

PGE-2, PGF-2 $\alpha, 6$-oxo-PGF-1 $\alpha$ and TXB-2 were measured using antisera raised in rabbits in this department and whose cross-reactivities have been reported elsewhere (Dighe, Emslie, Henderson, Rutherford \& Simon, 1975; Poyser, 1980, 1983; Poyser \& Scott, 1980). The only significant cross-reactivities are PGE-1 (94\%), PGB-2 (72.7\%) and PGA-2 (13.6\%) with the PGE-2 antiserum, and PGF- $1 \alpha(100 \%)$ with the PGF- $2 \alpha$ antiserum. The intra-assay coefficients of variation, calculated from the variation between the duplicate results obtained for each sample, were $9.2 \%$ (PGE-2), 8.6\% (PGF-2 $\alpha$ ), 8.2\% (6-oxo-PGF- $1 \alpha$ ) and $8.0 \%$ (TXB-2). The inter-assay coefficients of variation, calculated from the results obtained by incorporating a known amount of the appropriate compound into each assay, were $12 \cdot 6 \%$ (PGE- 2$), 11 \cdot 1 \%$ (PGF- $2 \alpha), 9 \cdot 7 \%$ (6-oxoPGF- $1 \alpha$ ), and $6 \cdot 1 \%$ (TXB-2). The detection limits per assay tube were 40 pg PGE-2, 40 pg PGF- $2 \alpha$, 40 pg 6-oxo-PGF-1 $\alpha$, and 30 pg TXB-2. 


\section{Statistical tests}

In Exp. 1 the results were analysed by Duncan's multiple range test. In the other experiments appropriate comparisons were made using Student's $t$ test, or a modified $t$ test if the variances were unequal by the variance ratio $F$ test.

\section{Results}

\section{Experiment I}

Analysis by GC-MS showed that PGE-2, PGF-2 $\alpha$, 6-oxo-PGF-1 $\alpha$, TXB-2 and PGD-2 were present in the extracts of incubated homogenates of rat ovaries. PGA-2, PGB-2, PGE-1 and PGF$1 \alpha$ were not detected in these extracts (detection limit 25-100 ng total, depending upon the PG). Consequently, the PGE-2 and PGF- $2 \alpha$ antisera were measuring predominantly the PG to which they had been raised.

The major PG produced by ovarian homogenates was PGI-2 (measured as 6-oxo-PGF-1 $\alpha$ ) with lesser quantities, in descending order, of PGF- $2 \alpha$, PGE-2 and TXA-2 (measured as TXB-2), throughout most of the oestrous cycle. PGD-2 was not measured, due to the lack of an RIA for this compound, but previous studies have shown it to be produced in similar quantities to PGE-2 between 10:00 h and 12:00 h on each day of the cycle (Poyser \& Scott, 1980). At 02:00 h of oestrus, PGE-2 was the major PG produced, and Text-fig. 1 shows the changes that occurred in ovarian PG and TX synthesizing capacities at 4 -h intervals during the 4-day oestrous cycle. The statistical analysis of the data is shown in Table 1.

PGE-2 production was low throughout most of the cycle, before increasing 5 -fold $(P<0.05)$ between 18:00 h on the day of pro-oestrus and $02: 00 \mathrm{~h}$ on oestrus. PGF- $2 \alpha$ production significantly increased $(P<0.05)$ between $06: 00$ and 10:00 h of pro-oestrus, but the value at 10:00 h was not significantly different from the values recorded on the morning of metoestrus or the late afternoon

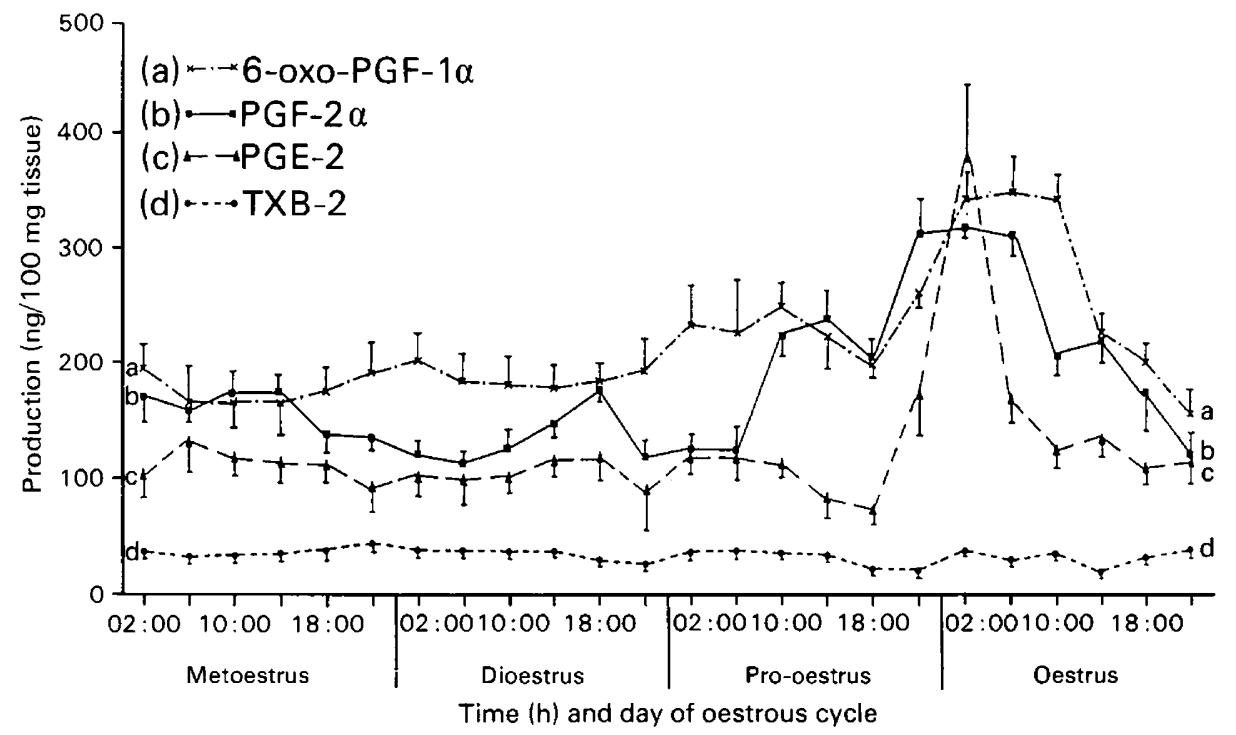

Text-fig. 1. Mean ( \pm s.e.m., for 6 determinations) production (ng/100 $\mathrm{mg}$ tissue) of prostaglandins (PGs) and thromboxane (TX) by rat ovarian homogenates in vitro at 4-h intervals throughout the 4-day oestrous cycle. See Table 1 for the statistical analysis of the results. 
Table 1. Statistical analysis of mean ( \pm s.e.m., for 6 determinations) prostaglandin (PG) and thromboxane (TX) production (ng/100 mg tissue) by rat ovarian homogenates in vitro

\begin{tabular}{|c|c|c|c|c|}
\hline Time & PGE-2 & PGF- $2 \alpha$ & 6-oxo-PGF- $1 \alpha$ & TXB-2 \\
\hline $02: 00 \mathrm{~h}$ metoestrus & $108+25^{\mathrm{ab}}$ & $171+22^{\mathrm{abcd}}$ & $194+22^{\mathrm{a}}$ & $38+5^{a}$ \\
\hline $06: 00 \mathrm{~h}$ metoestrus & $130 \pm 25^{\mathrm{ab}}$ & $160 \pm 12^{\mathrm{abcd}}$ & $165 \pm 32^{\mathrm{a}}$ & $33 \pm 4^{a}$ \\
\hline $10: 00 \mathrm{~h}$ metoestrus & $116 \pm 12^{\mathrm{ab}}$ & $168 \pm 20^{\mathrm{abcd}}$ & $164 \pm 20^{\mathrm{a}}$ & $34 \pm 5^{a}$ \\
\hline $14: 00 \mathrm{~h}$ metoestrus & $113 \pm 18^{\mathrm{ab}}$ & $170 \pm 17^{\mathrm{abcd}}$ & $163 \pm 25^{a}$ & $35 \pm 6^{a}$ \\
\hline $18: 00 \mathrm{~h}$ metoestrus & $112 \pm 18^{\mathrm{ab}}$ & $138 \pm 17^{\mathrm{ab}}$ & $175 \pm 20^{\mathrm{a}}$ & $39 \pm 8^{a}$ \\
\hline $22: 00 \mathrm{~h}$ metoestrus & $91 \pm 20^{\mathrm{ab}}$ & $135 \pm 10^{\mathrm{ab}}$ & $192 \pm 25^{a}$ & $44 \pm 7^{a}$ \\
\hline $02: 00 \mathrm{~h}$ dioestrus & $107 \pm 20^{\mathrm{ab}}$ & $121 \pm 11^{\mathrm{ab}}$ & $201 \pm 24^{a}$ & $38 \pm 5^{a}$ \\
\hline $06: 00 \mathrm{~h}$ dioestrus & $98 \pm 20^{\mathrm{ab}}$ & $114 \pm 9^{a}$ & $184 \pm 25^{\mathrm{a}}$ & $38 \pm 5^{a}$ \\
\hline $10: 00 \mathrm{~h}$ dioestrus & $104 \pm 15^{\mathrm{ab}}$ & $127 \pm 17^{\mathrm{ab}}$ & $181 \pm 25^{\mathrm{a}}$ & $37 \pm 4^{a}$ \\
\hline $14: 00 \mathrm{~h}$ dioestrus & $115 \pm 12^{\mathrm{ab}}$ & $148 \pm 12^{\mathrm{abc}}$ & $178 \pm 20^{\mathrm{a}}$ & $38 \pm 5^{a}$ \\
\hline $18: 00 \mathrm{~h}$ dioestrus & $119 \pm 20^{\mathrm{ab}}$ & $178 \pm 10^{\mathrm{abcd}}$ & $185 \pm 15^{\mathrm{a}}$ & $31 \pm 4^{a}$ \\
\hline $22: 00 \mathrm{~h}$ dioestrus & $90 \pm 32^{\mathrm{ab}}$ & $120 \pm 15^{\mathrm{ab}}$ & $193 \pm 30^{\mathrm{a}}$ & $28 \pm 5^{a}$ \\
\hline $02: 00 \mathrm{~h}$ pro-oestrus & $125 \pm 15^{\mathrm{ab}}$ & $126 \pm 12^{\mathrm{ab}}$ & $233 \pm 36^{a}$ & $38 \pm 4^{a}$ \\
\hline $06: 00 \mathrm{~h}$ pro-oestrus & $118 \pm 17^{\mathrm{ab}}$ & $126 \pm 20^{\mathrm{ab}}$ & $227 \pm 48^{a}$ & $39 \pm 7^{a}$ \\
\hline $10: 00 \mathrm{~h}$ pro-oestrus & $115 \pm 10^{\mathrm{ab}}$ & $225 \pm 18^{\mathrm{cd}}$ & $250 \pm 22^{\mathrm{ab}}$ & $38 \pm 7^{a}$ \\
\hline $14: 00 \mathrm{~h}$ pro-oestrus & $84 \pm 17^{\mathrm{ab}}$ & $240 \pm 22^{\text {der }}$ & $226 \pm 30^{a}$ & $36 \pm 7^{a}$ \\
\hline $18: 00 \mathrm{~h}$ pro-oestrus & $75 \pm 9^{a}$ & $200 \pm 20^{\mathrm{bc}}$ & $201 \pm 12^{\mathrm{a}}$ & $25 \pm 3^{\mathrm{a}}$ \\
\hline $22: 00 \mathrm{~h}$ pro-oestrus & $175 \pm 35^{b}$ & $313 \pm 30^{\text {ef }}$ & $262 \pm 12^{\mathrm{ab}}$ & $24 \pm 4^{a}$ \\
\hline $02: 00 \mathrm{~h}$ oestrus & $380 \pm 65^{c}$ & $320 \pm 10^{r}$ & $344 \pm 25^{\mathrm{b}}$ & $42 \pm 2^{a}$ \\
\hline $06: 00 \mathrm{~h}$ oestrus & $172 \pm 20^{\mathrm{b}}$ & $315 \pm 20^{f}$ & $350 \pm 32^{\mathrm{b}}$ & $35 \pm 5^{a}$ \\
\hline $10: 00 \mathrm{~h}$ oestrus & $126 \pm 13^{\mathrm{ab}}$ & $190 \pm 17^{\mathrm{abcd}}$ & $345 \pm 20^{\mathrm{b}}$ & $40 \pm 5^{a}$ \\
\hline $14: 00 \mathrm{~h}$ oestrus & $138 \pm 15^{\mathrm{ab}}$ & $230 \pm 22^{\text {cde }}$ & $230 \pm 17^{a}$ & $25 \pm 4^{a}$ \\
\hline $18: 00 \mathrm{~h}$ oestrus & $114 \pm 14^{\mathrm{ab}}$ & $169 \pm 25^{\mathrm{abcd}}$ & $205 \pm 17^{\mathrm{a}}$ & $38 \pm 7^{a}$ \\
\hline $22: 00 \mathrm{~h}$ oestrus & $125 \pm 23^{\mathrm{ab}}$ & $128 \pm 16^{\mathrm{ab}}$ & $162 \pm 23^{a}$ & $45 \pm 8^{a}$ \\
\hline
\end{tabular}

In any one vertical column, values with the same superscript are not significantly different $(P>0.05)$.

Table 2. Mean ( \pm s.e.m., for 3 determinations) concentrations ( $\mathrm{ng} / 100 \mathrm{mg}$ tissue) of prostaglandins (PGs) and thromboxane (TX) in rat ovaries

\begin{tabular}{lrrrr}
\hline \multicolumn{1}{c}{ Time } & \multicolumn{1}{c}{ PGE-2 } & \multicolumn{1}{c}{ PGF-2 $\alpha$} & 6-oxo-PGF-1 $\alpha$ & \multicolumn{1}{c}{ TXB-2 } \\
\hline $10: 00 \mathrm{~h}$ of pro-oestrus & $8 \cdot 22 \pm 0.42$ & $2.40 \pm 0.20$ & $2.87 \pm 0.04$ & $1.23 \pm 0.03$ \\
$02: 00 \mathrm{~h}$ of oestrus & $21 \cdot 40^{*} \pm 5 \cdot 70$ & $3 \cdot 70^{*} \pm 0.08$ & $5.81^{*} \pm 1.06$ & $1.61 \pm 0.31$ \\
\hline
\end{tabular}

* Significantly higher $(P<0.05)$ than corresponding value at 10:00 h of pro-oestrus.

of dioestrus. However, there was a further $1 \cdot 6$-fold increase $(P<0.05)$ between $18: 00 \mathrm{~h}$ of prooestrus and $02: 00 \mathrm{~h}$ of oestrus in PGF- $2 \alpha$ production. The production of 6-oxo-PGF- $1 \alpha$ and TXB-2 increased $1 \cdot 7$-fold also between these two times, but the increase was significant $(P<0.05)$ only for 6-oxo-PGF-1 $\alpha$.

\section{Experiment 2}

At $02: 00$ h of oestrus ovarian PGE-2, PGF- $2 \alpha$ and 6-oxo-PGF- $1 \alpha$ concentrations were 2.6-fold, $1 \cdot 5$-fold and $2 \cdot 0$-fold higher, respectively, than at $10: 00 \mathrm{~h}$ on pro-oestrus $(P<0 \cdot 05$ for each). TXB2 concentrations did not significantly increase between these times. PGE-2 was the major PG present at both times (Table 2). 


\section{Experiment 3}

The amounts (ng/100 mg tissue, mean \pm s.e.m., $n=4$ ) of PGE-2, PGF-2 $\alpha, 6$-oxo-PGF- $1 \alpha$ and TXB-2 produced by rat ovarian homogenates at 10:00 h on the day of pro-oestrus were, respectively, $115 \pm 12,223 \pm 21,250 \pm 20$, and $37 \pm 5$ in the absence of added exogenous arachidonic acid, and $132 \pm 25,172 \pm 37,240 \pm 67$, and $48 \pm 11$ in the presence of exogenous arachidonic acid $(2 \mu \mathrm{g} / \mathrm{ml})$. The addition of arachidonic acid had no significant effect on PG and TX production.

\section{Experiment 4}

Incubation of ovarian homogenates with $\left[{ }^{2} \mathrm{H}\right] \mathrm{PGE}-2$ or $\left[{ }^{2} \mathrm{H}\right] \mathrm{PGF}-2 \alpha$ resulted in the formation of compounds with $R_{\mathrm{F}}$ values corresponding to the 15-keto and 13,14-dihydro-15-keto metabolites of these PGs. The total percentage metabolism of each PG was low in the absence of NAD ${ }^{+}$, and did not vary between $10: 00 \mathrm{~h}$ of pro-ocstrus and $02: 00 \mathrm{~h}$ of oestrus. The addition of $\mathrm{NAD}^{+}$ significantly $(P<0.05)$ increased metabolism of both PGs at each time, with PGE-2 being metabolized to a greater extent than PGF-2 $\alpha$ (Table 3). However, there were no significant differences in the metabolism of PGE-2 or PGF-2 $\alpha$ in the presence of NAD ${ }^{+}$between 10:00 h of pro-oestrus and $02: 00 \mathrm{~h}$ of oestrus.

\section{Experiment 5}

There was no detectable conversion $(<2 \%)$ of $\left[{ }^{3} \mathrm{H}\right] \mathrm{PGF}-2 \alpha$ into $\left[{ }^{3} \mathrm{H}\right] \mathrm{PGE}-2$ by ovarian homogenates at $02: 00 \mathrm{~h}$ of oestrus in the absence or presence of $\mathrm{NADP}^{+}$. The conversion of $\left[{ }^{3} \mathrm{H}\right] \mathrm{PGE}-2$ into $\left[{ }^{3} \mathrm{H}\right] \mathrm{PGF}-2 \alpha$ by ovarian homogenates at $02: 00 \mathrm{~h}$ of oestrus was not detectable $(<2 \%)$ in the absence of NADPH, and was $6 \cdot 1 \pm 1.7 \%$ (mean \pm s.e.m., $n=3)$ in its presence. $\left[{ }^{3} \mathrm{H}\right] \mathrm{PGE}-2$ was also metabolized into 15 -keto-PGE-2 and 13,14-dihydro-15-keto-PGE-2, but the total percentage conversion (mean \pm s.e.m., $n=3$ ) into these 2 metabolites did not differ significantly in the absence $(19 \cdot 8 \pm 3 \cdot 3 \%$ ) or presence $(15 \cdot 2 \pm 1 \cdot 1 \%)$ of NADPH.

Table 3. Mean ( \pm s.e.m., for 4 determinations) percentage metabolism of PGE- 2 and PGF-2 $\alpha$ by rat ovarian homogenates

\begin{tabular}{|c|c|c|c|c|}
\hline \multirow[b]{3}{*}{ Time } & \multicolumn{4}{|c|}{$\%$ Metabolism } \\
\hline & \multicolumn{2}{|c|}{ PGE-2 } & \multicolumn{2}{|c|}{ PGF- $2 \alpha$} \\
\hline & Without NAD ${ }^{+}$ & With NAD ${ }^{+}$ & Without NAD ${ }^{+}$ & With NAD ${ }^{+}$ \\
\hline $10: 00 \mathrm{~h}$ of pro-oestrus & $10.1 \pm 1.02$ & $51 \cdot 3 \pm 13 \cdot 1^{*}$ & $11 \cdot 3 \pm 1 \cdot 5$ & $19 \cdot 5 \pm 3 \cdot 5^{*}$ \\
\hline $02: 00 \mathrm{~h}$ of oestrus & $11.6 \pm 2.2$ & $30.4 \pm 1.6^{*}$ & $9.3 \pm 1.6$ & $15 \cdot 0 \pm 2.0^{*}$ \\
\hline
\end{tabular}

* Significantly higher $(P<0.05)$ than corresponding value without $\mathrm{NAD}^{+}$.

Table 4. Mean ( \pm s.e.m., for 6 determinations) amounts (ng/mg protein) of PGE-2 synthesized from exogenous $\mathrm{PGH}-2$ by rat ovarian homogenates, i.e. $\mathrm{B}-(\mathrm{A}+\mathrm{C})$

\begin{tabular}{ccccc}
\hline \multicolumn{1}{c}{ Time } & A & B & C & B $-(\mathrm{A}+\mathrm{C})$ \\
\hline $10: 00 \mathrm{~h}$ of pro-cestrus & $23 \cdot 2 \pm 5 \cdot 2$ & $47 \cdot 6 \pm 6 \cdot 6$ & $5 \cdot 6 \pm 1 \cdot 1$ & $18 \cdot 6 \pm 4 \cdot 2$ \\
$02: 00 \mathrm{~h}$ of oestrus & $21 \cdot 1 \pm 4 \cdot 5$ & $36.4 \pm 2 \cdot 9$ & $4 \cdot 2 \pm 1 \cdot 5$ & $11 \cdot 1 \pm 1 \cdot 8$ \\
\hline
\end{tabular}

A, boiled homogenate PGH-2 added; B, non-boiled homogenate and PGH-2 added; C, non-boiled homogenate and no PGH-2 added. All homogenates contained flurbiprofen $(50 \mu \mathrm{g} / \mathrm{ml})$. 


\section{Experiment 6}

The last column in Table 4 shows the enzymic conversion of exogenous PGH-2 into PGE- 2 by rat ovarian homogenates. There was no significant difference between the values obtained at 10:00 $h$ of pro-oestrus and $02: 00 \mathrm{~h}$ of oestrus.

\section{Discussion}

The concentrations of PGE- 2 and PGF- $2 \alpha$ in the rat ovary were increased at the time of ovulation ( $\sim 02: 00 \mathrm{~h}$ on the day of oestrus), with PGE-2 showing the greater increase, which is in agreement with previous reports (Bauminger \& Lindner, 1975; LeMaire et al., 1975). We now report that the concentration of 6-oxo-PGF-1 $\alpha$ (which is indicative of PGI-2 production) is also increased in the rat ovary near the time of ovulation. LH stimulates PGI-2 production by cultured granulosa cells from swine, and this stimulation is prevented by protein synthesis inhibitors (Veldhuis, Klase \& Demers, 1982). This dependence of increased PGI-2 production on increased protein synthesis is similar to that of increased PGE-2 production (Clark et al., 1976; Zor et al., 1977). Indeed, stimulation of PGI-2 production by LH in rat granulosa cells in vitro occurs in parallel with the stimulation of PGE-2, and increased production of both PGs occurs only after a 3-h lag period (Koos \& Clark, 1982). PGE-2 production is 2-3 times higher than PGI-2 production (Koos \& Clark, 1982), which is similar to the difference in ovarian PGE-2 and 6-oxo-PGF-1 $\alpha$ concentrations found in the present study. These increases in PGI-2 and PGE-2 production may be responsible for the vasodilation that occurs in the walls of the preovulatory follicle before ovulation (Jones, 1979).

PG production by whole ovarian homogenates significantly increased after the LH surge (which occurs between 15:00 and 20:00 h in these rats; C. G. Brown \& N. L. Poyser, unpublished observations), but before ovulation. Since (i) the ovarian concentrations of PGs and TX are low, (ii) the lower production of PGs and TX on the morning of pro-oestrus is not due to lack of arachidonic acid, and (iii) the metabolism and interconversion of PGE-2 and PGF-2 $\alpha$ in the absence of cofactors are low, the increase in PG production between 18:00 h of pro-oestrus and $02: 00 \mathrm{~h}$ of oestrus must be due to an increase in the amounts of PGs synthesized. This increase in PG synthesis is most easily explained by an increase in the amount of PG synthetase contained within the ovary (probably the granulosa cells) which converts a correspondingly greater quantity of arachidonic acid into PGs, in agreement with previous studies (Bauminger \& Lindner, 1975; Clark et al., 1976, 1978; Zor et al., 1977). However, we have now shown that the syntheses of the different PGs and TX are not equally affected.

The increase in PGE-2 synthesis was 3 times greater than the increases in the syntheses of PGF$2 \alpha, 6$-oxo-PGF- $1 \alpha$ and TXB-2 between 18:00 $\mathrm{h}$ of pro-oestrus and $02: 00 \mathrm{~h}$ of oestrus. However, there is no increase in PGH-2 to PGE-2 synthetase activity between 10:00 h of pro-oestrus and $02: 00 \mathrm{~h}$ of oestrus, times of low and high PGE-2 synthesis respectively. It can be concluded, therefore, that, after the LH peak, it is the cyclo-oxygenase (PGH-2 synthetase) component of the PG synthetase enzyme complex which increases in activity, with the endogenous PGH-2 formed being preferentially directed in some way into the PGE-2-forming pathway. This greater stimulation of PGE-2 synthesis in comparison to the synthesis of the other PGs may be the explanation for the preferential increase in ovarian and follicular PGE-2 concentration found in the rat ovary just before ovulation (LeMaire et al., 1975; Bauminger \& Lindner, 1975). The finding that the administration of antiserum to cyclo-oxygenase inhibits ovulation in rats (Satoh $e t$ al., 1981 ) indicates the necessity of this enzyme and its products for follicular rupture in this species. In addition, the interconversion of PGE- 2 and PGF- $2 \alpha$ appears to have a minor role in regulating the amounts of these PGs formed in the rat ovary.

This study was supported by a grant from the M.R.C., and by a M.R.C. research studentship awarded to C.G.B. PHG-2 was kindly donated by Dr N. H. Wilson, Department of Pharmacology, University of Edinburgh. Other authentic PGs and TXB-2 were kindly donated by the Upjohn Co., U.S.A. 


\section{References}

Bauminger, S. \& Lindner, H.R. (1975) Periovulatory changes in ovarian prostaglandin formation and their hormonal control in the rat. Prostaglandins 9, 737751.

Behrman, H.R. (1979) Prostaglandins in hypothalamo pituitary and ovarian function. Ann. Rev. Physiol. 41, $685-700$.

Clark, M.R., Marsh, J.M. \& LeMaire, W.J. (1976) The role of protein synthesis in the stimulation by $\mathrm{LH}$ of prostaglandin accumulation in rat pre-ovulatory follicles in vitro. Prostaglandins 12, 209-216.

Clark, M.R., Marsh, J.M. \& LeMaire, W.J. (1978) Mechanism of luteinizing hormone regulation of prostaglandin synthesis in rat granulosa cells. J. biol. Chem. 253, 7757-7761.

Dighe, K.K., Emslie, H.A., Henderson, L.K., Rutherford, F. \& Simon, L. (1975) The development of antisera to prostaglandins $B_{2}$ and $F_{2 \alpha}$ and their analysis using solid phase and double antibody radioimmunoassay methods. Br. J. Pharmac. 55, 503-514.

Hamberg, M. \& Samuelsson, B. (1973) Detection and isolation of an endoperoxide intermediate in prostaglandin biosynthesis. Proc. Natn. Acad. Sci. U.S.A. 70, 899-903.

Jones, R.E. (1979) Control of follicular selection. In The Vertebrate Ovary, pp. 763-781. Ed. R. E. Jones. Plenum Press, New York.

Koos, R.O. \& Clark, M.R. (1982) Production of 6-ketoprostaglandin $\mathrm{F}_{1_{\alpha}}$ by rat granulosa cells in vitro. Endocrinology 111, 1513-1518.

eMaire, W.J., Leidner, R. \& Marsh, J.M. (1975) Pre and post ovulatory changes in the concentration of prostaglandins in rat Graafian follicles. Prostaglandins 9, 221-229.

Lindner, H.R., Zor, U., Bauminger, S., Tsafriri, A., Lamprecht, S.A., Koch, Y., Antebi, S. \& Schwartz, A. (1980) Significance of prostaglandins in the regulation of cyclic events in the ovary and uterus. In Advances in Prostaglandin and Thromboxane Research Vol. 8, pp. 1371-1390. Eds B. Samuelsson, P. W. Ramwell \& R. Paoletti. Raven Press, New York.

Lowry, O.H., Rosebrough, N.J., Farr, A. \& Randall, R.J. (1951) Protein measurement with the Folin phenol reagent. J. biol. Chem. 193, 265-275.
Mitchell, S., Poyser, N.L. \& Wilson, N.H. (1977) Effect of $p$-bromophenacyl bromide, as inhibitor of phospholipase $A_{2}$, on arachidonic acid release and prostaglandin synthesis by the guinea-pig uterus in vitro. Br. J. Pharmac. 59, 107-113.

Poyser, N.L. (1980) Development and use of a radioimmunoassay for measuring 6-oxo-prostaglandin $\mathrm{F}_{1_{\alpha}}$. In Prostaglandins, Prostacyclin and Thromboxanes Measurement, pp. 44-55. Eds J. M. Boeynaems \& A. G. Herman. Martinus Nijhoff, The Hague.

Poyser, N.L. (1983) Differential stimulation of prostaglandin and thromboxane synthesizing capacities in guinea-pig uterus and ovary. Prostaglandins, Leuk. \& Med. 10, 163-177.

Poyser, N.L. \& Scott, F.M. (1980) Prostaglandin and thromboxane production by rat uterus and ovary in vitro during the oestrous cycle. J. Reprod. Fert. 60, 3340.

Satoh, K., Fukouka, H., Wu, T., Mitsuhashi, N., Kinoshita, K. \& Sakamoto, S. (1981) Inhibition of superovulation in immature female rats by the antiserum to cyclooxygenase. Prostaglandins \& $\mathrm{Med}$. 7, 29-42.

Swan, C.G. \& Poyser, N.L. (1983) Prostaglandin synthesis by, and the effects of prostaglandins and prostaglandin analogues on, the vas deferens of the rabbit and rat in vitro. J. Reprod. Fert. 69, 91-99.

Tsafriri, A., Lindner, H.R., Zor, U. \& Lamprecht, S.A. (1972) Physiological role of prostaglandins in the induction of ovulation. Prostaglandins 2, 1-10.

Veldhuis, J.D., Klase, P. \& Demers, L.M. (1982) Luteinizing hormone stimulates the production of prostacyclin by isolated ovarian cell in vitro. Prostaglandins 23, 319-328.

Watson, J., Shepherd, T.S. \& Dodson, K. (1979) Prostaglandin E-2-9-keto-reductase in ovarian tissues. $J$. Reprod. Fert. 57, 489-496.

Zor, U., Strulovici, B., Nimrod, A. \& Lindner, H.R. (1977) Stimulation by cyclic nucleotides of prostaglandin $\mathrm{E}$ production in isolated Graafian follicles. Prostaglandins 14, 947-961. 